\title{
The Performance of Sovereign and Non-Sovereign Bonds and Their Relation towards Yields in Malaysia
}

\author{
Noriza Mohd Saad \\ Faculty of Business and Management, Universiti Teknologi MARA Machang Branch, Kelantan Malaysia.
}

\begin{abstract}
This study aims to investigates the significant mean different between the sovereign bonds and non-sovereign bonds performance with regards to their facets and to analyze the relationship of these bond facets towards their yield performance in Malaysia. Secondary data used for such government bond issuances cover the period of 2015-2020. The data gathered from Bank Negara Info Bond Hub website, Bloomberg and Malaysia Energy Information Hub and others for such a Malaysian government bond facets. The results show that there is a statistically significant mean different between two types of bonds, sovereign and non-sovereign whereby the performance of their facets could be in different patterns depending on fluctuation in price respectively. Besides, there is a significant relationship between the facets of these bonds such as price, tenure and amount of issues as well as control variables towards their yields. The outcome of the study provides a reference to stakeholders as well as government as an investment options that provide a permissible return to them.
\end{abstract}

Index Terms

Sovereign Bond, Non Sovereign Bond, Robust Performance, Yield, Malaysia

Article Received: 10 August 2020, Revised: 25 October 2020, Accepted: 18 November 2020

\section{Introduction}

Amongst the integral parts of the Malaysian capital market is bond market that has expanded rapidly by becoming as one of the largest markets in Asia. As at the end of 2010, the outstanding amount of bond was RM758.7 billion rose by $16.2 \%$ from RM653.2 billion in 2009. In 2010, the SC approved 52 private bond for issuance with a value of RM63.6 billion as compared with 34 approved issues with a value of RM57.5 billion in 2009 (SC,2010). Amongst these issuances, the main issuers of public debt are the Government of Malaysia, the central bank (Bank Negara Malaysia, henceforth as BNM), and quasi government institutions (Khazanah, Danamodal and Danaharta). The National Mortgage Corporation (Cagamas Berhad), financial institutions and non-financial corporations issue private bond and asset-backed securities.

The bond market in Malaysia has developed significantly in terms of market size, range of instruments and efficiency. The development of the bond market centers on the need to establish a well-diversified financial base to meet the changing needs of the Malaysian economy. Concerted measures to develop the bond market were taken by the Government, and success of these efforts are reflected in the significant growth of the bond market, marking Malaysian bond market as one of the fastest growing bond markets in Asia (BNM, 2012).

Government bond are marketable debt instruments issued by the government of Malaysia to raise funds from the domestic capital market to finance the government's development expenditure and working capital for their project transformation. BNM in its role as banker and adviser to the Government advises on the details of Government securities issuance include Malaysian Government Securities (MGS) and facilitates such issuance through various market infrastructures that it owns and operates.

Concerning the sovereign bonds, it refer to any bonds issued by a country's central government for fiscal reasons. They take different names and forms, depending on where they are issue, their maturities, and their coupon types. For example, Malaysia government bonds with an original maturity shorter than one year known as treasury bills. Sovereign bonds are usually unsecured and backed by the taxing authority of a national government. Credit rating agencies perform sovereign risk analysis in both local currency and foreign currency. The risk level of local and foreign currency is different. Generally, if an issuer is planning to default, it is more likely to do so with a foreign currency issue, as it has less control over foreign currency with respect to its exchange rate. In addition to that, sovereign bonds can be domestic bonds, foreign bonds and Eurobonds. They can be fixed-rate, floating-rate or inflationlinked bonds. For example, Treasury Inflation Protection Securities (TIPS) are T-notes or T-bonds that adjusted for inflation.

In the 2020, sovereign bonds will face the strategic challenge of achieving alignment with the Sustainable Development Goals. For sovereign bonds to develop the required resilience in the disruptive decade that lies ahead, decisive action is probably required from issuers, investors, credit rating agencies and international institutions, as well as researchers and civil society, to ensure the full value of nature is incorporated. Sovereign bonds are one of the largest asset classes with an outstanding global value of US\$66 trillion. They are also one of the systemic asset classes: sovereign bonds capture a range of macro-economic factors, influence broader capital market pricing and system stability and are core holdings for financial institutions (Pinzón, Robins, McLuckie and Thoumi, 2020).

With respect to the non-sovereign bonds, this are bonds issued by local governments. The sources of repayment proceeds are the general taxing authority of the issuer, project cash flows and special taxes. This type of bonds receives high credit ratings due to low default rates. They often trade at a higher yield than their sovereign 
counterparts do.

The remainder of the paper structured as follows. Section 2 includes review of literature on sovereign and non-sovereign bonds performance mostly from other countries since this area of study is probably still under research in Malaysia up to date since there is no previous study was found. Then, section 3 describes the data and variables used besides stated the research methodology applied where the statistic derived in this section to test the model hypothesis testing. Further, the results are discuss to show how the model can be apply by government in section 4 . Finally, section 5 summarizes some conclusions and recommendations.

\section{Literature Review}

Performance of government bonds are profoundly relying on the trading activities should be transparent, fully retrieved on yield information and market liquidation. Scholtens (2010) investigate the implications of using different indicators to assess the sustainability performance of Dutch government bond funds found that it does matter a lot which particular indicator is used. The study suggested that funds should be very transparent and straightforward about their non-financial performance. Besides, Carriero, Kapetanios and Marcellino (2010) proposed new approach by extracting information regards to large panel of yields efficiently to forecast the term structure of interest rates for future performance.

Yields changes lead to draw the performance movement of bond whereby Zhou (2011) apply Bayesian Model Averaging (BMA) to forecast the government bond yield changes and indicate BMA model can significantly outperform the random walk model at one-month-ahead horizon. In addition, Gruber and Kamin (2011) observed the impact of debt level on long-term government bond yields in the OECD over the period from 1988 to 2007. The result had shown a robust performance and significant effect of debt level on long-term bond yields.

In one hand, most of the study was recorded that the performance of government bond is performed in generating huge return through stabilization if yields. However, on the other hand it shown underperformed. For instance, Fujiwara, Körber and Nagakura (2013) was found that liquidity in government bond markets predicts the coefficient of skewness with a positive sign, meaning that the probability of a large and negative excess return is more likely in a less liquid market. In addition, a positive realized return is associated with a negative coefficient of skewness or a small probability of a large and negative return in the future.

Lekkos and Milas (2004) studied the behaviour of expected excess returns on UK government discount bonds of the sample from 1977:01 to 1986:06 reported that in the first half of study period, bond holders require high returns during recession periods and low returns during periods of expansion. This relationship reversed in the second half of the sample. Ferson, Henry and Kisgen (2003, 2006) stated that most government bond returned underperformed indicated below than average performance evaluation for US fixed income mutual funds from 1986 until 2000. The result was supported by Comer and Rodriguez (2006) examine four separate classifications (high quality corporate, general corporate, government Treasury, and general government) of investment grade bond funds over the 1994-2004 periods. The finding was documented a significant differences in performance as corporate funds outperform government funds on a risk adjusted basis. The performance results are robust to alternative evaluation metrics.

By comparing with three strong market economics countries, Fearnley (2002) investigates whether US, Japanese and European stock and government bond return indices are jointly price within a conditional multivariate form of the international Capital Asset Pricing Model during the period 1993-2001. It also explores the time variation of the price of market risk within this framework, allowing for a structural change in the prices of market and currency risk. The significant finding found to be better for the stock markets than for the bond markets. Then, Kumar and Okimoto (2011) researched on the dynamics of international government bond market integration in six of the G7 economies over two decades leading up to the global crisis. Result revealed that, the integration at the long end of the yield curve had been increasing, had become pronounced, nd was significantly greater than at the short end.

Bank, Kupfer and Sendlhofer (2012) proposed an innovative instrument of sovereign debt financing named Performancesensitive government bonds (PSGB) whereby its main characteristic are coupon payments associated to debt policy. The analysis has shown that this new instrument was create an important incentive for governments. In addition, the issuances of PSGB build up long-term reputation and lead to lower average financing costs to mitigate the longterm default risk premium and therefore ease budget constraints. Whilst a rising interest rate spread only has an effect on new or rolled-over debt, PSGB influence all debt outstanding, leveraging the consequences of policy decisions on governments.

In addition to that, Reschreiter (2004) mentioned that government could significantly reduce their cost of long term financing through issuing inflation index-linked debt. However, the issuances with maturities less than 3 years do not significantly reduce their risk compensation. The beta of the nominal bond proxy by coupon rate is lower than the beta of the real bond. Consequently, an estimated a singlelatent-variable model of predicted nominal and real bond excess returns suggests that a single time varying risk prices UK government bonds.

Instead of interest rate, other study linked the performance of government debt financing with inflation rate. For instance, Fung, Wai-Ming and Zhu (2000) analyzed an association of government debt financing with macroeconomic factors (inflation rate) in Chinese. Result was reveal that when Chinese government was heavily depends on debt financing to solve their budget deficit and interest payment obligation leads to reduce the output growth rate of the money supply, boost up inflation rate and the tax rate on labor income is sufficiently low.

Then, Reschreiter (2004) mentioned that government could significantly reduce their cost of long term financing through issuing inflation index-linked debt. However, the issuances with maturities less than 3 years do not significantly reduce their risk compensation. The beta of the 
nominal bond proxy by coupon rate is lower than the beta of the real bond. Consequently, an estimated a single-latentvariable model of predicted nominal and real bond excess returns suggests that a single time varying risk prices UK government bonds. Lekkos and Milas (2004) studied the behaviour of expected excess returns on UK government discount bonds of the sample from 1977:01 to 1986:06 reported that in the first half of study period, bond holders require high returns during recession periods and low returns during periods of expansion. This relationship is reverse in the second half of the sample.

According to Hegde (1987) examined the forecast performance of near-term of Treasury Bond futures contract traded on the Chicago Board of Trade reported that the contract fails to outperform the forecasting for long term interest rates investment. Similar finding of study stated by Samarakoon (1998), overall performance of Sri Lankan Treasury bond monthly portfolio shown rebalanced and appreciation both in account capital and bond returns for long-term interest rates portfolio investment.

Fung, Wai-Ming and Zhu (2000) analyzed an association of government debt financing with macroeconomic factors in Chinese. Result was reveal that when Chinese government was heavily depending on debt financing to solve their budget deficit and interest payment obligation leads to reduce the output growth rate of the money supply, boost up inflation rate and the tax rate on labor income is sufficiently low.

\section{Data and Methodology}

Secondary data used for unbalanced panel data that is segregate into three panel data, that are panel $\mathrm{A}$ is for pooled sample, $\mathrm{B}$ for sovereign bonds and $\mathrm{C}$ for non-sovereign bonds. Yield for both types of bond, sovereign and nonsovereign become dependent variable. Other variables such as price, tenure or year to maturity and amount of issues in Malaysian Ringgit (MYR) in million are independent variable. This study also considered Gross Domestic Product percapita (GDP), Consumer Price Index (CPI) and Energy Intensity percapita (Energy) as control variables.

The total sample of $n=2190$ of sovereign and non-sovereign bonds issuances was retrieved which is representing a full sample which is consist of $n=69$ and $n=2121$ respectively cover period of year 2015 to 2020 (up to October 2020 issuances). For the purpose of collecting information on the sovereign and non-sovereign bonds facets, this study obtained data from Malaysian central bank, Bank Negara Malaysia (BNM) Bond Info Hub and Bloomberg where there are sufficient for gathering data on coupon rates, types of instrument, size of issuance, price and yields. Concerning data for control variables, it retrieved from Malaysia Energy Information Hub (MEIH) statistics website.

In this study, yields is refers to the rate of return anticipated on a bonds if it is held until the maturity date which is considered a long-term government bond yields expressed as an annual rate. The equation for yield is state as below:

Yield $=c(1+r)^{\wedge}-1+c(1+r)^{\wedge}-2+\ldots+c(1+r)^{\wedge}-Y$

$+P(1+r)^{\wedge}-Y$

Where;

$\mathrm{c}$ is the annual coupon payment (in Malaysian Ringgit),

$\mathrm{Y}$ is the number of years to maturity, $r$ is the discount rate, and

$\mathrm{P}$ is the par value of the government bond.

This research study investigate the relationship between yield and independent and control variables using multiple regression approach for both regression model, either fixed effect (FE) or random effect (RE). The multiple regression for such relationship is represent by the model equations as follows:

Yieldit $=\alpha+b 1$ Priceit + b2Tenureit + b3Issueit + b4GDPit + b5CPIit+b6Energyit + eit, re $\quad$... RE Model

Yieldit $=\alpha+b 1$ Priceit $+b 2$ Tenureit + b3Issueit + b4GDPit + b5CPIit+b6Energyit + sit, fe _... FE Model Yieldit $=\alpha+b 1$ Priceit $+b 2$ Tenureit + b3Issueit + b4GDPit + b5CPIit+b6Energyit + eit, re robust $\quad \ldots$. RE Robust Model

where, the time period is denoted by the subscript $t$ $(\mathrm{t}=6, \mathrm{~T}=2015 \ldots 2020)$; types of issuances by the subscript $\mathrm{i}$ $(\mathrm{i}=2, \ldots, \mathrm{N}=2$ category, 2190 issuances); $\alpha$ represents constant term; and cit is the random error term.

Next, in order to select the best-fit model of relationship between dependent, yield and independent, price, tenure and amount issue, as well as control variables, Hausman Test performed. This is important step to identify the most appropriate model in making concluding remarks in explaining the relationship for both type of bonds. Then, it was follows by diagnostic check test on the model selection whereby the modified Wald-chi test for groupwise heteroskedasticity are tested either the variances are constant or not. The significant of probability chi-squared result conclude that there is a heteroskedasticity (variances are not constant) problem. Hence, the most appropriate model is determined based on the significant level of heterokedasticity results. If the chi-squared shows a significant result, then robust multiple regression estimations are required to perform on the selected model and if insignificant, the robustness is not required to that level. In this situation, the regression model will run using robust standard errors estimation to overcome or rectify the problem. As benefit of using the Stata, robustness check and test are, perform to resolve the problem.

Here with, this study developed the hypothesis to outfit for the pooling regression model as below:

H1: There is a significance means difference of sovereign and non-sovereign bond instruments as regards to their yield performance.

$\mathrm{H} 2$ : There is a relationship between sovereign and nonsovereign bond yields and its facets.

\section{Results and Discussion}

\section{A. Descriptive Statistics}

Table 1 revealed the overall performance of sovereign and non-sovereign bonds for minimum, maximum and mean value of utilized data in panel A, B and C. Amidst the period of studied, some of the sovereign and non-sovereign bonds issuances shown in zero coupon whereby the minimum value indicates 0.00 , however the yield for maximum value is at $5.26 \%$ and $15 \%$ for panel $\mathrm{B}$ and $\mathrm{C}$ respectively. It shows that the non-sovereign bonds indicates higher yield in overall performance. As suit to the government bond that offers more to risk free rate based 
with zero coupon, this yields performance look like stable for long-term investment without distressing losses.

In terms of bond price, the minimum shown at only MYR96.63 and maximum is at MYR100.00 with the average value of MYR99.57 for panel B whereby it shows much different to panel C, at minimum with MYR 66.91, maximum at MYR149.51 and in average mean of MYR99.73. This implies that the price movement was very volatile for panel $\mathrm{C}$ even though the mean value deviate to highest level representing the risk of creditworthiness bear impeded. This price performance are also associate to the tenure of the bond investment whereby the result show that panel B issue longer than panel C.

With respect to the amount of issuance, the original value indicating in Malaysian ringgit (MYR) in million shows that panel $\mathrm{C}$ issue more as compare to panel $\mathrm{B}$, however panel $\mathrm{B}$ issue higher minimum level than $\mathrm{C}$ with the average issuances for both types of bond is not much different at MYR181.5m and MYR200.22m for panel B and C respectively.

Table 1: Descriptive Statistics Results

Panel A Pooled Sample

\begin{tabular}{|c|c|c|c|c|c|}
\hline Variables & Obs & Mean & $\begin{array}{l}\text { Std. } \\
\text { Dev. }\end{array}$ & Min & Max \\
\hline Year & 2190 & 2017 & 1.57 & 2015 & 2020 \\
\hline Type & 2190 & 1.97 & 0.17 & 1 & 2 \\
\hline Yield & 2190 & 3.77 & 2.23 & 0 & 15 \\
\hline Price & 2190 & 99.73 & 2.36 & 66.91 & 149.51 \\
\hline Tenure & 2190 & 7.36 & 5.85 & 1 & 42 \\
\hline Issue & 2066 & 178.81 & 206.23 & 0.1 & 955 \\
\hline GDP & 2190 & 43256 & 4195 & 37123 & 50224 \\
\hline CPI & 2190 & 118.98 & 3.3 & 112.8 & 122.7 \\
\hline Energy & 2190 & 1.97 & 0.17 & 1.66 & 2.23 \\
\hline \multicolumn{6}{|c|}{ Panel B Sovereign Bond } \\
\hline Year & 69 & 2017 & 1.17 & 2015 & 2020 \\
\hline Yield & 69 & 2.55 & 2.16 & 0 & 5.26 \\
\hline Price & 69 & 99.57 & 0.74 & 96.63 & 100 \\
\hline Tenure & 69 & 9.35 & 10.28 & 1 & 42 \\
\hline Issue & 43 & 529.07 & 181.5 & 200 & 900 \\
\hline GDP & 69 & 440004 & 3139 & 37123 & 50224 \\
\hline CPI & 69 & 119.77 & 2.46 & 112.8 & 122.7 \\
\hline Energy & 69 & 1.98 & 0.12 & 1.66 & 2.23 \\
\hline \multicolumn{6}{|c|}{ Panel C Non Sovereign Bond } \\
\hline Year & 2121 & 2017 & 1.58 & 2015 & 2020 \\
\hline Yield & 2121 & 3.8 & 2.22 & 0 & 15 \\
\hline Price & 2121 & 99.73 & 2.4 & 66.91 & 149.51 \\
\hline Tenure & 2121 & 7.3 & 5.65 & 1 & 38 \\
\hline Issue & 2023 & 171.37 & 200.22 & 0.1 & 955 \\
\hline GDP & 2121 & 43510 & 4225 & 37123 & 50224 \\
\hline CPI & 2121 & 118.96 & 3.32 & 112.8 & 122.7 \\
\hline Energy & 2121 & 1.96 & 0.17 & 1.66 & 2.23 \\
\hline
\end{tabular}

\section{B. One-way Analysis for Yield Comparisons}

Table 2 Mean Different Results

\begin{tabular}{llllll}
\hline Source & SS & df & MS & F & F \\
\hline $\begin{array}{l}\text { Between } \\
\text { type }\end{array}$ & 105.073041 & 105.07304 & 21.28 & 0.000 \\
$\begin{array}{l}\text { Within } \\
\text { type }\end{array}$ & 10805.013 & 2188 & 4.9383057 & \\
\hline
\end{tabular}

Results from mean comparison in table 2 shown that there is a significant mean different between yields of sovereign and non-sovereign bonds at $99 \%$ confident level with $\mathrm{F}$ value of 21.28. The result postulate that yield performance for both types of both have a different patterns even though their facets is the same and traded under the similar capital market place. Theoretically, lower coupon rate will be increase the price of the bonds and versed versa that affect to yield performance. Therefore, it can be concluded that, H1 was accepted since the results was revealed that yield have shown a significant mean different between these two type of bonds instrument in Malaysia.

\section{Regression Analysis}

Table 3: Multivariate Regressions Results Panel A Pooled Sample

\begin{tabular}{|c|c|c|c|}
\hline & RE & FE & RE Robust \\
\hline Constant & $-4.100 * * *$ & $-7.22 * * *$ & $-2.64 * * *$ \\
\hline Price & $8.750 * * *$ & $8.63 * * *$ & $3.080 * * *$ \\
\hline Tenure & $16.910 * * *$ & $19.94 * * *$ & $17.36^{* * *}$ \\
\hline Issue & $-2.780 * * *$ & $-2.78 * * *$ & $-3.520 * * *$ \\
\hline GDP & 0.09 & & 0.09 \\
\hline CPI & $2.150 * *$ & & $2.100 * *$ \\
\hline Energy & $-1.950 *$ & & $-1.960 * *$ \\
\hline Observations & 2066 & 2066 & 2066 \\
\hline R-Square & $18.10 \%$ & $16.33 \%$ & $18.10 \%$ \\
\hline Wald chi2 & $454.90 * * *$ & - & $472.94 * * *$ \\
\hline F-Value & - & $126.02 * * *$ & - \\
\hline BP-LM & $0.65(0.4216)$ & & \\
\hline RE Effect & Yes & & \\
\hline FE effect & - & Yes & \\
\hline \multicolumn{4}{|c|}{ Panel B Sovereign Bond } \\
\hline & $\mathbf{R E}$ & FE & RE Robust \\
\hline Constant & $-7.160 * * *$ & $-7.32 * * *$ & $-3.95 * * *$ \\
\hline Price & $7.790 * * *$ & $7.45^{* * *} *$ & $3.630 * * *$ \\
\hline Tenure & $4.610 * * *$ & $4.47 * * *$ & $4.180 * * *$ \\
\hline Issue & -0.780 & $-0.730 * * *$ & $-1.150 * * *$ \\
\hline GDP & $-2.230 * *$ & & $-2.060 * *$ \\
\hline CPI & $1.860 *$ & & $2.450 * *$ \\
\hline Energy & 1.12 & & 0.98 \\
\hline Observations & 43 & 43 & 43 \\
\hline R-Square & $85.55 \%$ & $79.96 \%$ & $85.55 \%$ \\
\hline Wald chi2 & $213.07 * * *$ & - & $422.04 * * *$ \\
\hline
\end{tabular}




\begin{tabular}{|c|c|c|c|}
\hline F-Value & - & 0.000 & - \\
\hline BP-LM & $2.39(1.222)$ & & \\
\hline RE Effect & Yes & & \\
\hline FE effect & - & Yes & \\
\hline \multicolumn{4}{|c|}{ Panel C Non Sovereign Bond } \\
\hline & $\mathbf{R E}$ & FE & RE Robust \\
\hline Constant & $-4.090 * * *$ & $-6.970 * * *$ & $-2.680 * * *$ \\
\hline Price & $8.500 * * *$ & $8.370 * * *$ & $3.060 * * *$ \\
\hline Tenure & $16.510 * * *$ & $16.56^{* * *}$ & $16.850 * * *$ \\
\hline Issue & $-2.100 * *$ & $-2.11 * *$ & $-2.740 * * *$ \\
\hline GDP & 0.35 & & $-0.350 * *$ \\
\hline CPI & $2.260 * *$ & & $2.200 * *$ \\
\hline Energy & $-2.200 * *$ & & $-2.190 * *$ \\
\hline Observations & 2023 & 2023 & 2023 \\
\hline R-Square & $17.83 \%$ & $16.08 \%$ & $17.83 \%$ \\
\hline Wald chi2 & $437.49 * * *$ & - & $456.08 * * *$ \\
\hline F-Value & - & $120.75 * * *$ & - \\
\hline BP-LM & $0.49(0.4853)$ & & \\
\hline RE Effect & Yes & & \\
\hline FE effect & - & Yes & \\
\hline
\end{tabular}

Note: $* * *, * * \& *$ denotes the significant level at $99 \%, 95 \%$ \& $90 \%$ respectively.

Based on results presented in Table 3, unbalanced panel data are applied for the tests since panel $\mathrm{A}$ and $\mathrm{B}$ indicate unequal number of observations in their issuances and period, cover the fixed effects (FE) and random effects (RE) models. The diagnostic check test was performed on the model selection whereby the modified Wald-chi test for groupwise heteroskedasticity are tested either the variances are constant or not. The significant of probability chisquared result conclude that there is a heteroskedasticity (variances are not constant) problem. Hence, the most appropriate model is determined based on the significant level of heterokedasticity results. If the chi-squared shows a significant result (in this case, all panels A, B and C indicate a significant at 99 percent confident level for all models), then robust multiple regression estimations are required to perform on the selected model and if insignificant the robustness is not required to that level. In this situation, the regression model will run using robust standard errors estimation to overcome or rectify the problem. As benefit of using the Stata, robustness check and test are, perform to resolve the problem. Besides, the study revalidates the result with Bruesh Pagan-Lagrarian Multiplier (BP-LM) diagnostic tests to determine which models i.e; RE or FE, is the best-fit and most appropriate model in explaining the relationship between yield and it facets as well as control variables with heterokedasticity problem. The BP-LM test results (panel $\mathrm{A}$ at $0.65, \mathrm{~B}$ at 2.39 and $\mathrm{C}$ at 0.49 which is all models reported insignificant result) shown that $\mathrm{RE}$ is the most appropriate model to explain such relationship with robust effect to rectify the heterokedasticity problem.

In addition to that, R-square reported for the model estimation of regression in order to investigate the percentage of relationship from the sovereign and nonsovereign bonds facets as explanatory variation in explaining the yield. The result also reveals the satisfactory and acceptable value of R-square for about $18.10 \%, 85.55 \%$ and $17.83 \%$ for panel $\mathrm{A}, \mathrm{B}$ and $\mathrm{C}$ in the most appropriate model, RE robust regression respectively. These implies that for instance, yield under panel A have about $18.10 \%$ affected by the bonds facets performance and control variables such GDP, CPI and energy intensity that much probably stakeholder do an investment in the sector.

In Overall, the finding shows that yield for sovereign and non-sovereign bonds are significant at 99 percent confident level in all models, panel A, B or C. Besides, the result also reported that the association is consistent among panel; for instance, there are significant positive relationship between yield performance with price and tenure but inverse relationship with the amount of issue. Concerning the control variables, the result shown different significant level for all panel where yield have a significant relation towards CPI and energy intensity in pooled sample, panel A but insignificant relation with GDP. Contrast result reveal by panel B whereby CPI shown insignificant and all control variables shown significant in panel $\mathrm{C}$. Means that, the bonds issuances either sovereign and non-sovereign have different factor in determining their performance especially yield. Therefore, the study accept the $\mathrm{H} 2$.

Table 4: Pairwise Correlations Results

Panel A Pooled Sample

\begin{tabular}{|c|c|c|c|c|c|c|c|c|}
\hline Var & $\begin{array}{l}\mathrm{Ob} \\
\mathrm{S}\end{array}$ & $\begin{array}{l}\text { Yie } \\
\text { ld }\end{array}$ & $\begin{array}{l}\text { Pri } \\
\text { ce }\end{array}$ & $\begin{array}{l}\text { Tenu } \\
\text { re }\end{array}$ & $\begin{array}{l}\text { Iss } \\
\text { ue }\end{array}$ & $\begin{array}{l}\text { GD } \\
\mathrm{P}\end{array}$ & $\begin{array}{l}\mathrm{CP} \\
\mathrm{I}\end{array}$ & $\begin{array}{l}\text { Ener } \\
\text { gy }\end{array}$ \\
\hline Yiel & 21 & 1.0 & & & & & & \\
\hline \multirow[t]{2}{*}{ d } & 90 & 0 & & & & & & \\
\hline & 21 & 0.1 & 1.0 & & & & & \\
\hline Price & 90 & 9 & 0 & & & & & \\
\hline Tenu & 21 & 0.3 & 0.0 & & & & & \\
\hline \multirow[t]{2}{*}{ re } & 90 & 6 & 4 & 1.00 & & & & \\
\hline & 20 & 0.0 & 0.0 & & 1.0 & & & \\
\hline \multirow[t]{3}{*}{ Issue } & 66 & 6 & 7 & 0.30 & 0 & & & \\
\hline & & - & - & & & & & \\
\hline & 21 & 0.1 & 0.0 & - & 0.0 & 1.0 & & \\
\hline \multirow[t]{3}{*}{ GDP } & 90 & 8 & 1 & 0.11 & 4 & 0 & & \\
\hline & & - & - & & & & & \\
\hline & 21 & 0.1 & 0.0 & - & 0.0 & 0.9 & 1.0 & \\
\hline \multirow[t]{2}{*}{ CPI } & 90 & 7 & 4 & 0.12 & 5 & 5 & 0 & \\
\hline & & - & - & & & & & \\
\hline Ener & 21 & 0.1 & 0.0 & - & 0.0 & 0.9 & 0.9 & \\
\hline gy & 90 & 7 & 2 & 0.10 & 5 & 9 & 7 & 1.00 \\
\hline
\end{tabular}

\begin{tabular}{|c|c|c|c|c|c|c|c|c|}
\hline Panel & B & Sov & eign & & & & & \\
\hline Yiel & & 1.0 & & & & & & \\
\hline d & 69 & 0 & & & & & & \\
\hline & & 0.2 & 1.0 & & & & & \\
\hline Price & 69 & 6 & 0 & & & & & \\
\hline Tenu & & 0.4 & 0.7 & & & & & \\
\hline re & 69 & 5 & 0 & 1.00 & & & & \\
\hline & & 0.1 & 0.1 & & 1.0 & & & \\
\hline Issue & 43 & 3 & 8 & 0.33 & 0 & & & \\
\hline & & 0.2 & 0.0 & & $\overline{0}-\overline{0}$ & 1.0 & & \\
\hline GDP & 69 & 5 & 3 & 0.22 & $\begin{array}{l}2 \\
-\end{array}$ & 0 & & \\
\hline & & 0.2 & 0.0 & & 0.2 & 0.9 & 1.0 & \\
\hline CPI & 69 & 9 & 5 & 0.13 & 6 & 3 & 0 & \\
\hline Ener & 69 & 0.9 & 0.3 & 0.15 & 0.2 & - & 0.9 & 1.00 \\
\hline
\end{tabular}




\begin{tabular}{|c|c|c|c|c|c|c|c|c|}
\hline \multicolumn{2}{|l|}{ gy } & 8 & \multicolumn{2}{|l|}{6} & 7 & $\begin{array}{l}0.1 \\
9\end{array}$ & \multicolumn{2}{|l|}{8} \\
\hline \multicolumn{9}{|c|}{$\begin{array}{l}\text { Panel C Non Sovereign } \\
\text { Bond }\end{array}$} \\
\hline Yiel & 21 & 1.0 & & & & & & \\
\hline \multirow[t]{3}{*}{$\mathrm{d}$} & 21 & 0 & & & & & & \\
\hline & & - & & & & & & \\
\hline & 21 & 0.0 & 1.0 & & & & & \\
\hline Price & 21 & 1 & 0 & & & & & \\
\hline Tenu & 21 & 0.0 & 0.3 & & & & & \\
\hline \multirow[t]{2}{*}{ re } & 21 & 4 & 6 & 1.00 & & & & \\
\hline & 20 & 0.0 & 0.0 & & 1.0 & & & \\
\hline \multirow[t]{3}{*}{ Issue } & 23 & 7 & 6 & 0.29 & 0 & & & \\
\hline & & - & - & & & & & \\
\hline & 21 & 0.0 & 0.1 & - & 0.0 & 1.0 & & \\
\hline \multirow[t]{3}{*}{ GDP } & 21 & 2 & 8 & 0.13 & 4 & 0 & & \\
\hline & & - & - & & & & & \\
\hline & 21 & 0.0 & 0.1 & - & 0.0 & 0.9 & 1.0 & \\
\hline \multirow[t]{2}{*}{ CPI } & 21 & 5 & 7 & 0.13 & 5 & 5 & 0 & \\
\hline & & - & - & & & & & \\
\hline Ener & 21 & 0.0 & 0.1 & - & 0.0 & 0.9 & 0.9 & \\
\hline gy & 21 & 2 & 8 & 0.12 & 5 & 3 & 1 & 1.00 \\
\hline
\end{tabular}

Table 4 reported the p-value of correlation are relatively low (correlations value less than 0.7) justifiable that no multicollinearity problems exist among independent variables exclude control variables as mentioned by Gujarati (1995). Results was shown that yield have positively significant correlated with independent variables. Mixed results reported to other variables.

\section{Discussion And Conclusion}

This study investigates the significant mean different of yield for sovereign and non-sovereign bonds issue in Malaysia capital market. In addition to that, the study also analyze about the relationship between yield and it facets as well as control variables. Evidently, results revealed that there are significant mean different of bond yield for sovereign and non-sovereign. The fluctuation in yields as measurement of return for this bonds as a long-term investment need to look into details their facets changes in ensuring the transformation execution can be enhances for sustainable economics in capital market not only in Malaysia but also can endeavor global market. With respect to the relationship between yield and its facets for both instruments, sovereign and non-sovereign, the result reveal that are significant at $99 \%$ confident level for all the panel, A, B and C. With that, this study would recommend for the future research, other variables such as government policies and other macroeconomic factors can be consider in investigating the performance of sovereign and nonsovereign and maybe could consider other types of government bonds. The study also believe that more sample periods should be used and maybe indicate better comparison performance if the sample was cross the countries
References

[1] Bank, M., Kupfer, A. and Sendlhofer, R. (2012), “ Performance-Sensitive Government Bonds", (July 12, 2012). Midwest Finance Association 2013 Annual Meeting Paper. Available at SSRN: http://ssrn.com/abstract $=1949117$ or http://dx.doi.org/10.2139/ssrn.1949117

[2] Bank Negara Malaysia (2012), Report Release

[3] Comer, G. and Rodriguez, J. (2006), "Corporate and Government Bond Funds: An Analysis of Investment Style, Performance, and Cash Flows", (September 11, 2006). Available at SSRN: http://ssrn.com/abstract $=929490$ or http://dx.doi.org/10.2139/ssrn.929490

[4] Carriero, A., Kapetanios, G. and Marcellino, M. G. (2012), "Forecasting Government Bond Yields with Large Bayesian Vector Autoregressions". Journal of Banking \& Finance, No. 36 pp. 2026-2047.

[5] Fearnley, T. A. (2002), "Estimation of an International Capital Asset Pricing Model with Stocks and Government Bonds", (July 2002). Research Paper $\mathrm{N}^{\circ}$ 95. pp. 1123. Available at SSRN: http://ssrn.com/abstract $=477465 \quad$ or http://dx.doi.org/10.2139/ssrn.477465

[6] Ferson, W. E., Henry, T. R. and Kisgen, D. J. (2003), "Evaluating Government Bond Fund Performance with Stochastic Discount Factors", (September 10, 2003). 14th Annual Conference on Financial Economics and Accounting (FEA). Available at SSRN: http://ssrn.com/abstract=488165 or http://dx.doi.org/10.2139/ssrn.488165

[7] Ferson, W. E., Henry, R. R. and Kisgen, N J. (2006), "Evaluating Government Bond Fund Performance with Stochastic Discount Factors". The Review of Financial Studies, Vol. 19, Issue 2, pp. 423-455, 2006.

[8] Fujiwara, I., Körber, L. M. and Nagakura, D. (2013), "Asymmetry in Government 
Bond Returns". Journal of banking \& finance, 37 (8). pp. 3218-3226.

[9] Fung, M. K., Ho, W. and Zhu, L. J. (2000), "Stagflationary Effect of Government Bond Financing in the Transforming Chinese Economy: a General Equilibrium Analysis". Journal of Development Economics, Vol. 61, No. 1, February 2000. Available at SSRN: http://ssrn.com/abstract $=238630$

[10] Gruber, J. W. and Kamin, S. B. (2011), "Fiscal Positions and Government Bond Yields in OECD Countries", (January 5, 2011). FRB International Finance Discussion Paper No. 1011. Available at SSRN: http://ssrn.com/abstract $=1769927$ or http://dx.doi.org/10.2139/ssrn.1769927

[11] Gujarati, D. (1995), "Basic Economics", McGraw-Hill Singapore.

[12] Kumar, M. S. and Okimoto, T. (2011), "Dynamics of International Integration of Government Securities' Markets”, Journal of Banking \& Finance 35, pp. 142-154.

[13] Lekkos, I.. and Milas, C. (2004), “Timevarying Excess Returns on UK Government Bonds: A Non-linear Approach", Journal of Banking \& Finance 28, pp. 45-62.

[14] Pinzón A and Robins N with McLuckie M and Thoumi G (2020). "The sovereign transition to sustainability: Understanding the dependence of sovereign debt on nature - Summary". London: Grantham Research Institute on Climate Change and the Environment, London School of Economics and Political Science, and Planet Tracker. Available at: https://www.lse.ac.uk/granthaminstitute/w p-content/uploads/

[15] Reschreiter, A. (2004), “Conditional Funding Costs of Inflation-indexed and Conventional Government Bonds", Journal of Banking \& Finance 28 , pp. 1299-1318.

[16] Samarakoon, L. P. (1998), "An Index to Measure the Performance of the Sri Lankan Treasury Bond Market",
(December 1998). Sri Lankan Journal of Management, Vol. 3, pp. 204-220.

[17] Scholtens, B. (2010), "The Environmental Performance of Dutch Government Bond Funds", Journal of Business Ethics, Vol. 92, Issue 1, pp. 117-130.

[18] Securities Commission (2010), Annual Report.

[19] Zhou, H. (David) (2011), “Incorporating Model Uncertainty and Model Instability in Forecasting Bond Risk Premia and Term Structure of Government Bond Yield - A Bayesian Model Averaging Approach", (October 24, 2011). Available at SSRN:

http://ssrn.com/abstract=1948869 or http://dx.doi.org/10.2139/ssrn.1948869 